\title{
New Perspectives on Language, Oral Transmission, and Multilingualism in Commedia dell'Arte
}

Whereas traditional scholarship has paid attention to the visual, physical, and philological aspects of commedia dell'arte, recent research acknowledges and examines the difficult-to-recover verbal performance aspects of this theatrical form. This essay highlights new work on the relationship between oral and textual culture in commedia dell'arte, examines how the improvisatory nature of commedia dell'arte affects language, and considers the important element of multilingualism.

Language in commedia dell'arte is both enticing — due to the reliance on improvisation and oral competence - and unusually chimerical, in that this oral performance form left a reduced foot print. The lack of evidence resulting from the commedia dell'arte's reliance on scenarios rather than fully scripted plays is compounded by the fact that commedia actors intentionally left little written evidence of their performances, in order to guard against competitive fellow actors. Despite these challenges, new scholarly work has begun to acknowledge the important interplay between the scripted and the verbal, in both oral and textual form. By identifying commedia as a material reflection of culture in its day and recognizing that important information can still be gleaned from scripted plays, scholars have managed to widen their pool of sources. Additionally, productive conversation between researchers and performers about language in orally-transmitted culture, together with a re-examination of underexposed archival materials, has unfolded new possibilities in the ways that we both configure commedia dell'arte and re-imagine other early modern oral performance forms.

This essay considers advances in the research on language and commedia dell'arte by focusing on oral transmission, on performance, and above all on multilingualism, a salient but particularly neglected feature of commedia dell'arte that has only recently begun to gain the scholarly attention it merits. Attention to multilingual communication greatly enhances how we understand commedia's oral dimensions. Of special interest are grammelot or nonsense language, a unique technique developed by commedia dell'arte comici, and the use of hybrid languages to create a discourse on cultural intermeshing.

Since the 1980s, increasing numbers of scholars have referred to erudite texts in order to glean information about oral performance. ${ }^{1}$ A number of recent publications on the early modern period also pay attention to lan- 
guage and particularly oral transmission. ${ }^{2}$ As this generation of research has shown, commedia dell'arte is not a purely improvisatory theatre but one in which actors performed scripted and scenario-based plays, often participating in literary discourse in the context of academies as well as in the streetbased, piazza performances that they shared with mountebanks. ${ }^{3}$ Much new research reflects work in the field of cultural history (or historical anthropology), where attention to language has been particularly significant. Recent studies by Peter Burke in particular closely examine relationships between language and community, where language is, in Burke's terms, 'a sensitive indicator — though not a simple reflection — of cultural change'. ${ }^{4}$ In Burke's perspective, the term 'indicator' is important to coaxing out a two-way relationship between language and culture, where language can be seen as both shaping culture, and indicative of the cultural forces which, in turn, shape it. Performative use of language reflects on intercultural encounters by engaging in a deliberation of its own use by mocking, celebrating or reshaping language. As I show, multilingualism in performance is one vehicle through which commedia dell'arte actors deliberated on the contemporary shaping of national languages.

The role of language is clearly fundamental to studies of commedia dell'arte. The dilemma regarding the use of textual traces and scripted plays inhibited prior generations of scholars, who made a clear distinction between the oral and the literary. Because commedia is in effect an anti-literary form, its performances are necessarily historically un-recoverable. The acceptance of commedia as a mixed literary-oral form, however, allows the scholar much greater freedom in terms of documentation. Louise Clubb, Richard Andrews, and Robert Henke, for example, have shown that much can be gleaned from commedia's textual traces, and that from these sources information can be extrapolated in ways that enable new conjectures regarding performance. ${ }^{5}$ Clubb herself makes an extended case for the cross fertilization between Shakespeare's plays and the scenarios of commedia dell'arte. ${ }^{6}$ Julie Campbell examines the ways that commedia's types of the female influenced Shakespeare's Love's Labour's Lost. ${ }^{7}$ Henke provides many examples of literary and oral elements drawn from Italian performers and explores how performance reflects their combination:

[T] he Italian professional theatre melded orality and literature: the oral forms, linguistic patterns, and techniques of early-modern piazza and banquet performers; and the literate forms, verbal structures, and modes of consciousness disseminated 
by manuscript and the print revolution into the script-based theatre of the courts and the academy. ${ }^{8}$

For both Clubb and Henke, in particular, the fruitful contamination among genres in Italian theatre suggests the mixture's presence in other cultural contexts, notably English theatre.

Nowhere are such literary and oral inter-dynamics more apparent than in the work of commedia dell'arte actresses. Celebrated actresses such as Isabella Andreini, for example, were largely responsible for edifying commedia and enhancing its literary elements. ${ }^{9}$ The praise lavished on Vincenza Armani by her fellow actor and lover Adriano Valerini in his lament upon her death in 1569 , moreover, underscores how important verbal eloquence was to the reputation of commedia actresses. ${ }^{10}$ At the same time, the actress found ways of going beyond the depiction of the Innamorata alone, knowing that it was cross-dressing, nudity, and more extreme behavior that would enable her to entice audiences. As M.A. Katritzky writes:

To facilitate their escape from the prescribed domestic spaces of female roles, and more fully explore and realize their potential as performers, these women created and starred in a wide range of disguises, drawn from the spheres of gender, race, age, mental competence, and social class. They embraced cross-dressed roles as diverse as gypsies, beggars, pilgrims, and slaves of either gender; madwomen, pageboys, soldiers; even a Syrian astrologer or their own elderly father, as creative passports to new dramatic territory - in terms of performance modes as well as theatrical space - traditionally monopolized by men. ${ }^{11}$

By mimicking other character types and taking on many of the actions normally associated with the buffoni, the actress showed proficiency in many of commedia's performative registers. A woman player's verbal enactments, however, formed one of the most important vehicles through which she could depart from the roles prescribed to her as a woman.

The surrender to language by a female character, like the performance of madness, has been shown to reverberate across the Channel to England. New studies of Shakespeare's Hamlet, for example, have reflected on the degree to which Ophelia embodies a female-gendered voice quite different from that of the male character. Suggesting that Ophelia's fragmentary mad speech actually reveals the presence of a community of female listeners in the audience, Mary Ellen Lamb writes: 'The oral traditions Ophelia performs in her distractions 
provide a pointed contrast — a bookend — to the wildly gendered fantasies composing Macbeth'. ${ }^{12}$ Natasha Korda suggests that Ophelia's 'wayward wanderings and unsolicited solicitation in her mad scene' evoke 'the figure of the female crier in the minds of Elizabethan playgoers, her snatches of old ballads drawing on the repertoire of the female crier of ballads, and her offering of herbs on that of the ubiquitous herb-wives of London'. ${ }^{13}$ Campbell has related the performances of commedia dell'arte actresses to characters such as the women in Love's Labour's Lost:

In addition to the dancing and acting associated with the escadron volant and commedia actresses, ladies of the French court and the Italian actresses were also known for their ability to participate in learned discourse on numerous topics of interest to humanists as well as to how to engage in ribald badinage. Thus, the sober and wise discourse of the ladies of Love's Labour's Lost, like their mischievous, sometimes lascivious, wordplay, has precedents in Continental female performance. $^{14}$

These studies by Korda, Lamb, and Campbell suggest a connection between the continental performances of commedia dell'arte actresses and those of Shakespeare, in the shared gendered language of the characters.

My own current research addresses questions regarding audience comprehension of the early-modern commedia dell'arte, given that so many dialects and languages were co-present in performance. ${ }^{15} \mathrm{I}$ regard language as both material of the commedia performance and the subject of the performance, and consider that the audience gained as much pleasure from witnessing language play as it did from the plots and characters developed on stage. I draw on the Bakhtinian explanation of languages 'warring' with one another, an idea also present in Burke's formulation that languages in the Renaissance 'naturally influenced or "interfered" with one another'. ${ }^{16}$ This dynamic helps me to understand how commedia dell'arte evolved certain performative techniques, such as grammelot as well as the development of what I term 'translingual' speech types for characters such as the zanni, the foreigners and the Capitani. Aspects I examine include the different ways in which the Innamorata used language and multilingualism as compared with her male counterparts on stage. Drawing examples from a variety of sixteenth- to eighteenth-century performances but mainly from the late sixteenth and early seventeenth centuries, the 'Golden Age' of commedia troupes, I analyze how expressivity and meaning in multilingual performance derive out of the theatrical frame in 
which they are present. Since seasoned commedia dell'arte audiences were familiar with characters and understood the scenic dynamic, the actors had more flexibility for linguistic experimentation.

The 'mischievous, sometimes lascivious, wordplay' Campbell attributes to the female characters of commedia and Shakespeare alike is evident in the commedia actress's frequent fusion of more than one language in her performances. This allowed her to depict the gypsies, Levantine characters, and madwomen for which she was so popular. Vittoria Piissimi, noted by Tommaso Garzoni as 'this divine Vittoria, who creates metamorphoses of her self on stage, this beautiful witch of love, who entices the hearts of thousands of lovers with her speech, this sweet Siren, who enchants with her sweet words the soul of her devoted audience', has also been famously inscribed into history in a performance of an unruly gypsy. ${ }^{17}$ Gigio Artemio Giancarli's play La Zingana was published in 1545. In a play of the same name staged in 1589, Piissimi plays a gypsy who returns to Treviso fifteen years after having kidnapped a child and now attempts to make good by returning the young man to his home. Although La Zingana is, as Andrews notes, an example of a fully scripted commedia erudita, Giancarli himself was a performer, which may indicate why the play appears to record spoken language, especially in segments of the gypsy's text. ${ }^{18}$ Marvin Carlson, who pays special attention to Renaissance Italian drama and its influence on other contemporary and modern performances, identifies Giancarli and Andrea Calmo as 'the last bridging figures' between commedia dell'arte and commedia erudite in their function as performers as well as writers. ${ }^{19}$ Elements in La Zingana associated with both written comedy and oral performance include the gypsy's explanation of how she would find the home from which she robbed the young boy:

I don't know for sure, but there have been about fifteen years and I have searched so, so much, and I don't know nothing for sure. But, if I find the house, where I took you, if the front of the house hasn't changed, I would know it ... by this sign, which is above the door which is a very, very nice figure of a gypsy, dressed in our gypsy clothes. ${ }^{20}$

Aspects of oral transmission appear here in the repetition of words such as el-beith (in the house) and the repeated self-translation of el-beith, el casa, the rhyming of casa with faza (face or façade), the alliteration of belo, bela, and the rhythmic quality of meliè, meliè, all of which not only facilitate memorization but also make the babble-like mélange a bit more accessible to the 
listening ear. Another striking aspect of this scene is the mixture of languages, which scholars have claimed includes Berber, Arabic, and Hebrew, as well as a deformed Italian. ${ }^{21}$ This variety of languages forges an identity for Piissimi that is much broader than a European one, an identity in which there is ethical and moral latitude. This multilingual aspect of the performance, moreover, garnered attention and praise for Piissimi. As Frances Barasch reminds us, 'Zorzi suggests that, when Pavoni wrote that Vittoria's impersonation of the Gypsy was a "rare marvel to hear," he was probably alluding to her ability to imitate ciangottolare, the unusual speech of Giancarli's protagonist; that is, she could speak badly, swallowing $r s$ and $l s$, lisp as a child, or sound a bird-like twitter'.22

The arguably even more famous actress Isabella Andreini showcased her virtuosic ability by singing in French, and dissembling or speaking in a myriad other languages. In the same wedding celebrations of 1589 in which Piissimi performed the gypsy, in honour of Archduke Ferdinando de' Medici and Christine of Lorraine, Andreini played an equally unruly part - that of a madwoman. Giuseppe Pavoni's description of this performance highlights Andreini's verbal skills in embracing a variety of languages. Isabella 'like a mad creature roamed the city scene, stopping one passerby, then another, speaking now in Spanish, now in Greek, now in Italian and in many other languages, but always irrationally; and among other things she began to speak French and to sing French songs'. ${ }^{23}$ The linguistic ability the actress needed in order to sing in French is undeniable, but the fact that Isabella spoke or dissembled speaking Greek as well as other languages suggests a mimic linguistic ability as well. Not surprisingly, when Garzoni wrote about Isabella, his hyperbolic compliments relied on language as a metaphor: 'The gracious Isabella is a decoration of the scene, an ornament of the theatre, a proud vision of virtue no less than of beauty, who has adorned her profession so much that so long as the world exists, while the centuries last, while times and seasons have life, every tongue, every voice, every language will echo the famous name of Isabella'. ${ }^{24}$ Furthermore, in her Lettere, attributed to her posthumously by her husband, Isabella Andreini herself reflected a heightened awareness of language, when she lamented the inability to speak in all the languages of the world in order to protest the injustices of a lover: 'I am sorry', she wrote, 'not to have [the ability to speak] all the languages of all the nations of the world'. ${ }^{25}$

The ease with which the actress expresses a consciousness of other languages reflects the broader culture, as evident from Burke's many examples. ${ }^{26}$ 
Until recently, however, little attention had been paid to this important aspect of commedia outside philological studies. A notable exception is Andrea Perrucci, whose treatise of 1699 is the first work to seriously study the languages of commedia dell'arte, providing not only descriptions of the types of dialogues and speeches but also explanations of the rules governing these expressions. ${ }^{27}$ Only relatively recently have scholars of the theatre recognized the importance of multilingualism in both shaping commedia aesthetics and participating in broader cultural deliberations on intercultural contact. ${ }^{28}$ Gianrenzo P. Clivio's important essay, which specifically focuses on languages and commedia, laments that the 'multilingual character of the improvisations has so far been investigated very little. ${ }^{29}$ Clivio notes that the sheer number of examples of multilingual scenarios he provides makes the case that this clearly central aspect of commedia has garnered insufficient scholarly attention. The numerous examples, coupled with the fact that these performances toured throughout and in some cases beyond Europe, also suggests the influence of multilingualism in a number of other contexts in which the commedia dell'arte was staged. Pierre Pathelin, Timoneda's Aurelia, Velez's Diablo conjuelo, and Bartolomé de Torres Naharro's Comedia Tinellaria include a variety of languages, as do various scripted English plays. For example, Shakespeare's Henry $V$ includes the famous 'language acquisition scene' between Henry and Katherine (3.4) in which Alice acts as translator. In Henry IV Part $I$ Welsh is intermingled with English (3.1). Thomas Middleton's A Chaste Maid in Cheapside also includes Welsh (1.1) and later even macaronic Latin (Act 4), while Thomas Dekker's The Shoemaker's Holiday combines Dutch (or pseudo-Dutch) with English (1.4). In these plays, although languages are used to mimetic ends, i.e. to reflect a multilingual reality, multilingualism is also used to comedic effect when the characters pretend to speak a language not their own. This dual purpose to using languages is increasingly present in Renaissance dramas in which 'multilingualism was being developed as a device in its own right, in which simple realism was constantly giving way to linguistic experiment and sheer comic fantasy'. ${ }^{30}$

If comic ends were the goal, then commedia dell'arte led the way in terms of innovative techniques designed to create a speech type that was itself 'sheer comic fantasy'. Dario Fo identifies this language as grammelot, defined by him as

a term of French origin, coined by Commedia players, and the word itself is devoid of meaning. It refers to a babble of sounds which, nonetheless, manage to convey 
the sense of a speech. Grammelot indicates the onomatopoeic flow of a speech, articulated without rhyme or reason, but capable of transmitting, with the aid of particular gestures, rhythms and sounds, an entire, rounded speech. ${ }^{31}$

Although Fo himself provides no early modern leads, I have traced grammelot back to a French sixteenth-century equivalent, grammellotte, defined as 'imaginary words'. ${ }^{32}$ Another possible variant is the word Grumello, the name of a locale not far from Bergamo. On the map, this area in the northern Italian region associated with the zanni or servant role is called 'Grumello dei Zanchi'. ${ }^{33}$ Grammelot is also etymologically associated with grumble, implying dissatisfaction, as in hungry body grumbles, thought to be derived from the French grommeler, defined as a murmur 'of discontent or dissatisfaction'. ${ }^{34}$ Interestingly, Fo frequently performs the grammelot of the 'Starving Zanni', an enactment of hunger and starvation in which he pieces together grumbles and rumbles of the hungry stomach to enact a kind of imaginary language of starvation. 35

Grammelot offers important insights into the ways in which multilingualism functioned radically within commedia performances. An exploration of grammelot in performance discloses the mechanics of meaning formation, through the production of suggestive sounds that are semantically meaningless. Its semblance of language is created by composites of gibberish that emulate language. The beauty of grammelot was its inclusiveness. Because no prior knowledge of a given language was required, it effectively gave touring companies the means for transnational communication. Grammelot not only conditioned a supple performative technique but created a buffoonish aesthetic that upped the ante from normative language-based performances. Furthermore, grammelot broached language through non-language and in that sense provided a meta-performative commentary. It allowed actors to dissemble 'losing themselves' in the buffoonish performance, while maintaining a critical distance through their linguistic mastery of an imaginary language. Primarily, though, grammelot attacked the idea of language as restrictively nationalistic, and mocked language as a project of civilization by endeavouring to reduce the speaker to a mere sound-spewing mechanism or an animal.

In support of this argument one need only think of Domenico Biancolelli, the seventeenth-century commedia dell'arte actor affectionately known to his Parisian audiences as Dominique. Biancolelli describes his enactment of Harlequin in the scenario The German Baron (Baron todesco - Le baron allemande) in his own zibaldone (diary), inscribing the grammelot he employed as 
he explained to the character Trivelin how his food was stolen by a 'thieving' cat: 'Then, I leave the house, pretending to chew something and I yell "stop thief?" and I tell him [Trivelin] that as I was eating a good piece of meat this thief [a cat] grabbed it from me, taking it while saying gniao, gniao and I ran after'. ${ }^{36}$ This description inscribes various sounds of 'gniao, gniao', providing a telling trace of the repertory of sounds the actor must have employed. The sounds suggest the degree to which the imaginary language was specific and consistent throughout various performances.

Multilingualism in commedia dell'arte is a recurring and consistent element and has been recognized as such. However, the ways in which its presence in performance reflects on contemporary culture remain curiously under-explored. In fact, attending to multilingualism can teach us much about how early modern people processed such aspects of daily life as interchange among cultures, and encounters with foreigners. Multilingualism in performance appears to have captured the ambivalence inherent to these interactions. From this perspective, the examination of multilingualism in a number of commedia dell'arte scenarios, zibaldone descriptions, and eyewitness accounts suggests that commedia performers recognized the complexity inherent in cultural identification, beyond the patina of buffoonish antics. Though commedia dell'arte meditated on culture in a humorous and often irreverent way, multilingualism nonetheless often facilitated the kind of reflection posited by modern contemporary cultural theorists.

This ambivalence is most marked in the performance of the character Capitano, who often represented marauding armies of Spanish or Swiss soldiers. Along with his bombasts, verbal copiousness, and abundant references to sex and violence, the Capitano also blended languages to create a kind of hybrid speech, amalgamating Spanish and Italian, or German and Italian. ${ }^{37}$ But in contrast with our acceptance and celebration of cultural hybridity today, Capitano's linguistic mixtures indicated the derisively comic attitude the audience held towards him. An exceptionally well-known Capitano is Francesco Andreini, husband of Isabella Andreini and head of the Gelosi commedia dell'arte troupe. Like Biancolelli, Francesco Andreini left behind him a textual trail that enhances our ability, in hindsight, to access the language of his performance. In Le bravure, his two-part record of the Captain's bombasts, Andreini inscribes scenes that he performed as the character Capitano Spavento, and records his dialogues with his servant Trappola. ${ }^{38}$

As an opposing counterpart to Isabella's linguistic surrender to language, and her lamentation regarding her inability to know all the languages of the 
world, Capitano Spavento, Francesco's alter ego, suggests he has the linguistic upper hand by declaring himself 'master of all the languages and all the subjects, and all sciences'. ${ }^{39}$ But just as the Capitano type usually covers up his cowardliness with bravura, Andreini's Capitano Spavento may be said to exhibit a parallel linguistic bravura in which his supposed 'mastery' of languages doesn't hold true. Since the set expectations of the Capitano are that he bites off more than he can chew, his claim implies mere bombast with no actual backing to it. The audience arguably assumed the Capitano was linguistically limited and accepted Isabella's claim not to know other languages. Pan-linguistic mastery, then, in either character, is expressed as an impossibility. The irony, of course, is that both actors were exceptionally multilingual. As ideological 'mouthpieces', their characters may have suggested the unattainability of multilingual competence, but the meta-theatrical reality was quite different. In performance, the linguistic abilities of both were evident, particularly in the case of Isabella, who described herself as a 'citizen of the world' in the dedication to her Lettere. ${ }^{40}$

Other female performers, too, displayed considerable linguistic and multilingual proficiency, whose theatrical effect was to leave audiences spellbound. ${ }^{41}$ Isabella's ability to speak or dissemble speech in a variety of languages was commensurable with this early modern cosmopolitanism. Consonant with her ability, Francesco Andreini, who had learned some Turkish while held prisoner by the Turks, also knew quite a few languages. The Capitano fulfills his verbal bombast by displaying a refracted linguistic competence in his attempts to speak Arabic. In one comic scene for example, he claims to speak Arabic but actually speaks a blend of Arabic and Turkish mixed with Italian: 'Salamalecchi, benum, Saltanum. ${ }^{42}$ Performatively, the replacing of one language by another suggests that the audience was either in on the joke or unaware of the difference. Inadvertently, both Turks and Arabs were derided, as were the larger political forces they symbolized. But at the same time, since Andreini's substitution of Turkish for Arabic probably went unnoticed by the audience, the cultural opacity of the Turks and the Levantines was indirectly reified. Although this was not the primary intent of the linguistic enactment, it probably was palpable. After all, Francesco's bombast as Capitano (about knowing all languages) and Isabella's lament (about not knowing all the languages of the world) reflected a consciousness of linguistic 'otherness'. The comic, then seems to have been intermingled with a more solemn recognition of each audience member's limitations - the singular boundaries of comprehension indicative of larger cultural ambivalences. This 
meta-theatrical dimension to performances that were, on the face of it, buffoonish and simplistic suggests a much more complicated way in which commedia dell'arte, through its use of language and particularly multilingualism, reflected on the changed world surrounding its players and audiences. That English theatre at the time also provided multilingual vignettes in works by Shakespeare and Dekker is further evidence for the importance of the performative practice in reflecting its changing world. Through this intercultural contact, individuals were made aware of their distinctiveness from or similarity to others and for that reason were constantly negotiating identity. Cultural historical research into the commedia dell'arte has also initiated a number of perspectives on the multiculturalism implicit in theatrical form. ${ }^{43}$ Similarly, Marvin Carlson addresses the Renaissance multilingual theatre within the broader context of multilingualism in theatre, historically situating the early modern as a key moment for sedimenting the use of multilingualism, as it transitions from purely oral to oral and literary production. ${ }^{44}$

Research into how multilingualism influenced the commedia dell'arte and its place in early modern cultural deliberations suggests necessary and illuminating avenues for the future. Identifying a transition from using multilingualism for verisimilitude to using it for comedy necessitates further exploration as to its effect on the performances. Additional studies of less studied texts such as Giancarli's Zingana could disclose more about the ways in which commedia dell'arte represented the language of cultural others. ${ }^{45} \mathrm{New}$ work on gendered language in English and Italian comedy reveals connections between popular and literary culture. Furthermore, the radical possibilities of grammelot suggest that commedia performed a cultural intervention, by creating a temporary communicative structure unique to each historic moment, linking audience members of different linguistic backgrounds. Finally, studies of language in commedia reveal how performance could create a nexus for socio-linguistic contemplation including reflections on the permutations of language in culture, the gendered nature of language, and the tremendous shifts in language taking place around early modern people. 


\section{Notes}

1 See Louise George Clubb, Italian Drama in Shakespeare's Time (New Haven, 1989); Richard Andrews, Scripts and Scenarios: The Performance of Comedy in Renaissance Italy (Cambridge, 1993); Robert Henke, Performance and Literature in the Commedia dell'Arte (Cambridge, 2002).

2 Mary Ellen Lamb and Karen Bamford (eds), Oral Traditions and Gender in Early Modern Literary Texts (Aldershot, 2008).

3 See M.A. Katritzky, 'Was Commedia dell'Arte Performed by Mountebanks? Album Amicorum Illustrations and Thomas Platter's Description of 1598', Theatre Research International 23.2 (1998), 104-25; Robert Henke, 'The Italian Mountebank and the Commedia dell'Arte', Theatre Survey 38.2 (1997), 1-29; Bella Mirabella "'Quacking Delilahs": Female Mountebanks in Early Modern England and Italy', Pamela Allen Brown and Peter Parolin (eds.), Women Players in England, 1500-1660, Beyond the All-Male Stage (Aldershot, 2005), 89-105; Rosalind Kerr's essay in this issue.

4 Peter Burke, Languages and Communities in Early Modern Europe (Cambridge, 2004), 1.

5 In addition, Andrews in Scripts and Scenarios has shown that the scripted has strong connections to the improvised and that the oral and written are closely related. Henke in Performance and Literature has further developed the idea that orality and literary production are closely linked in a period that was still residually oral. He shows that oral performances were themselves highly influenced by the advent of print which led to the publication of poems, leaflets, and books, themselves sources for performance.

6 Clubb, Italian Drama.

7 See Julie D. Campbell, "Merry, nimble, stirring spirit[s]": Academic, Salon and Commedia dell'Arte Influence on the Innamorate in Love's Labour's Lost', Brown and Parolin (eds), Women Players, 145-70.

8 Henke, Performance and Literature, 1.

9 See Anne MacNeil, Music and Women of the Commedia dell'Arte in the Late Sixteenth Century (Oxford, 2003); Rosalind Kerr, 'The Actress as Androgyne in the Commedia dell'Arte Scenarios of Flaminio Scala' (Doctoral Dissertation, University of Toronto, 1993).

10 Oratione D'Adriano Valerini Veronese, in morte della divina signora Vincenza Armani, Comica Eccellentissima. For an extensive discussion, see Henke Performance and Literature, 96-100. 
11 M.A. Katritzky, The Art of Commedia: A Study in the Commedia dell'Arte with Special Refernt to the Visual Records 1560-1620 (Amsterdam, 2006), 200-1.

12 Mary Ellen Lamb, 'Introduction', in Lamb and Bamford (eds), Oral Traditions, xix.

13 Natasha Korda, 'Gender at Work in the Cries of London', in Lamb and Bamford (eds), Oral Traditions, 134.

14 Campbell, "'Merry, nimble, stirring spirit[s]"', 158.

15 These issues are addressed in detail in Erith Jaffe-Berg, The Multilingual Art of Commedia dell'Arte (Ottawa, forthcoming).

16 Burke, Languages and Communities, 120.

17 Tommaso Garzoni, La Piazza universale di tutte le professioni del mondo (Venice, 1586), 738-9. Unless otherwise noted, all translations are my own.

18 Andrews, Scripts and Scenarios, 144-54.

19 Marvin Carlson, Speaking in Tongues: Language at Play in the Theatre (Ann Arbor, 2006), 76.

20 Giancarli, La Zingana, in Lucia Lazzarini, Commedie (Padua, 1991), 285.

21 On the language of the gypsy, see Andrews, Scripts and Scenarios, 150; Ireneo Sanesi, Storia dei generi letterari Italiani: La Commedia (Milan, 1911), 1: 425.

22 Frances K. Barasch, 'Italian Actresses in Shakespeare's World: Vittoria and Isabella', Shakespeare Bulletin 19.3 (2001), 6.

23 Pavoni in Clubb, Italian Drama, 263-4.

24 Garzoni, La Piazza universale, 738.

25 '[D]ebbo dolermi di non haver tutte le lingue, di tutte le nationi del mondo'. Attributed to Isabella Andreini, Querele Contra Amour, in Lettere (Venezia, 1607).

26 For a discussion of polyglotism among individuals and in locales, see Burke, Languages and Communities, 118, 120-2. For individual consciousness regarding different languages, see 66-7.

27 Andrea Perrucci, Dell'arte rappresentativa premeditate ed all'improvviso (Naples, 1699). Perrucci's treatise sets down the rules associated with various characters' speech and provides a valuation of the appropriateness of the various dialects, but does not contextualize the theatrical use of the various languages within culture. See the 2008 bilingual English-Italian edition of Francesco Cotticelli, Anne Goodrich Heck and Thomas F Heck (discussed in M.A. Katritzky's essay in this issue).

28 Folena, Cortelazzo, and Clivio draw on Perruci's treatise to briefly explore the various speech types of commedia characters, without contextualizing the use of multilingualism. Gianfranco Folena, 'Les Langues de la Comédie et la Comédie des Langues', trans. from Italian to French by Anne Denis, in Christian Bec and Irène Mamczarz (eds), Le Theater Italien et l'Europe: XVe-XVII Siècles (Paris: Presses Universitaires de France, 1983), 27. M. Cortelazzo, 'La figura e la lingua del "todesco" nella let- 
tertura veneziana rinascimentale', in Scritti in onore di Giuliano Bonfante (Bresciia, 1976). Gianrenzo P. Clivio, 'The Languages of the Commedia dell'Arte' in Domenico Pietropaolo (ed.), The Science of Buffoonery: Theory and History of the Commedia dell'Arte (Toronto, 1989), 209.

29 Clivio, 'Languages of the Commedia dell'Arte', 209.

30 Andrews, Scripts and Scenarios, 144.

31 Dario Fo, The Tricks of the Trade [translated from Manuale minimo (1987)], Stuart Hood (ed.) (London, 1991), 56.

32 Erith Jaffe-Berg, 'Forays into Grammelot: The Language of Nonsense', Journal of Dramatic Theory and Criticism 15.2 (2001), n. 14.

33 Grande dizionario enciclopedico UTET (Pietro Fedele ed.) $3^{\text {rd }}$ ed. (Turin, 1969), 9: 544.

34 Oxford English Dictionary, $2^{\text {nd }}$ ed. (Oxford, 1989), 6: 904. See also Jaffe-Berg, 'Forays', 9.

35 On this issue, see also Erith Jaffe-Berg, 'Language, Food and the Hierarchy of Values in the Commedia dell'Arte Performances from the Renaissance to the Eighteenth Century', European Studies Journal 12-13 (2000-1), 115-30; Robert Henke, 'Representations of Poverty in the Commedia dell'Arte', Theatre Survey 48.2 (November 2007), 229-46.

36 Biancolleli in Spada, Domenico Biancolelli ou l'art d'improviser; Textes, documents, introduction, notes (Naples, 1969), 46. See also Jaffe-Berg, 'Forays', 8.

37 For more on the bombastic references made by the Capitano, see Henke, Performance and Literature, 176-9. See also Cesare Molinari, La Commedia dell'Arte (Milan, 1985), 116.

38 Francesco Andreini, Le bravure del Capitano Spavento (1607; 1615), Roberto Tessari (ed.), (Pisa, 1987).

39 Francesco Andreini, Le bravure, 36.

40 Andreini, Lettere, dedication, $2^{\text {nd }}$ unnumbered page: ('Cittadina del Mondo').

41 See notes 17 and 24 above.

42 Le bravure del Capitano Spavento, 36 (sixth Ragionamento). See also Jaffe-Berg, The Multilingual Art of Commedia.

43 Robert Henke and Eric Nicholson (eds), Transnational Exchange in Early Modern Theater, (Aldershot, 2008).

44 Carlson, Speaking in Tongues.

45 Domnica Radulescu initiates this exploration in 'Performing the female Gypsy: Commedia dell'Artes' "tricks" for finding freedom', in Valentina Glajar and Domnica Radulescu (eds), 'Gypsies' In European Literature and Culture (Basingstoke, 2008), 193-216. (See also M.A. Katritzky's article in this issue). 